The Effect of Teaching Innovation

\section{on Learning Effectiveness among the Students of Taiwan and Mainland China Universities}

\author{
Yu-Ting Huang \\ Shih Hsin University, Taiwan \\ ythuang@mail.shu.edu.tw \\ Tzong-Ru Lee \\ National Chung Hsing University, Taiwan \\ trlee@dragon.nchu.edu.tw \\ Yi-Jyu Jiang \\ National Chung Hsing University, Taiwan \\ ucashieve@gmail.com
}

\begin{abstract}
This paper presents a teaching innovation that has proved successful in stimulating the in-class participation and learning effectiveness of Asian students. The sample population of the research was the teachers and the students of universities in Taiwan and Mainland China. Convenience sampling was used. Grey Relational Analysis (GRA) was used to explore the feedback of learning course. The research results showed that (1) students in Taiwan and Mainland China both have a good confidence in attendance and teamwork projects at the beginning of the course and; (2) Taiwanese students are confident in their own creativity and application ability at the beginning of the course and students from Mainland China have a regular habit of reading relevant marketing books.
\end{abstract}

Keywords - teaching innovation, learning effectiveness, Grey Relational Analysis, cross-cultural research

\section{Introduction}

Practice teaching is the essential supplement to the traditional theory teaching. Providing new answers to the question of how to teach and learn innovation enables higher education institutions to effectively pursue their task to contribute to social economic renewal. However, not many higher education institutions do pay attention, or succeed well in performing their societal duties, including their roles in industrial, regional and national innovation systems. Hampden-Turner's (2009) study indicated that there are
The Effect

of Teaching Innovation

on Learning Effectiveness among the Students of Taiwan and Mainland China Universities 
IJSR 7 good reasons to be sceptical about teaching innovation and a closely related activity, entrepreneurship. The main challenge is that innovation deviate from what had existed earlier because the objective is to generate novel combinations, which outperform the previous ones. We know surprisingly little about the preparation for practice teaching that occurs in the university context, particularly with respect to these more practiceoriented classes (Clift and Brady, 2005). What we do know has more to do with titles of these courses, or their place in the curriculum, than with how these courses are taught. How to strengthen the practical teaching, and to improve the training quality, is an important and urgent task for the undergraduate teaching in higher institutions. On the other hand, from the point of view of the professional characteristics, marketing is a very practical field of study, graduate students of marketing not only need to have a solid theoretical foundation, but also a strong ability to solve practical problems faced by the enterprises. Therefore, the process of teaching marketing must attach importance to the training of students' operating and management skills, through the establishment of the practice teaching system in order to train students in terms of practical ability.

Overall, the constant renewal of teaching methods and the integration of practice teaching into teaching shall bring a relatively effective foundation between teaching and learning for teachers and students. In addition, students' willingness to learn and their learning effectiveness can be enhanced. This study was attempted to verify and comprehend whether there was an interaction effect of teaching innovation and integrating information technology into teaching as far as students' learning effectiveness in higher education institutions in Taiwan and Mainland China is concerned. Therefore, the specific purpose of the study can be summarised as follows:

1) To verify and comprehend whether teaching innovation has a positive, significant, direct effect on learning effectiveness of higher education institutions in Taiwan and Mainland China.

2) To find out whether the results of this study can be used as a reference when higher education teachers are developing teaching methods.

\section{Literature review}

\subsection{Learning effectiveness}

This literature stems from cognitive psychology and analyses of the constituent elements of learning. These elements located at the higher end of the learning process characterise by one's desire to comprehend and absorb a topic during the years of formal education. Nowadays, there also are more and more challenges for graduate students of marketing, who have to learn more theoretical skills and practical ability to face their future jobs in the industry. These range from the quantitative increase of one's notions and knowledge to learning as an interpretative process aimed at the understanding of reality (e.g. Saljo, 1979), and to changing as a person (e.g. Marton et al., 1993). Furthermore, learning performance will be affected by teaching, course design, learning styles and other factors (Loo, 1999). Jones (1996) shared this view as well. However, the traditional classification of students according to learning attitudes includes "deep" learners, the ideal type where students engage in the understanding of meaning (Biggs, 1987); 
"surface", learners where students memorise and reproduce information (Biggs, 1987); and "achieving" learners, where students focus predominantly on grades (Entwistle and Ramsden, 1983). Therefore, the conceptual definition of "learning effectiveness" is the ability "to use teaching and learning innovation after graduating, to demonstrate professional skills, and the capability to participate in various external exams, etc. as the indicators of measurement for learning effectiveness".

Teachers are thus vitally significant in terms of influencing students' development or redirecting them to deep learning attitudes, particularly when they adopt teaching methods that focus on students' learning rather than content delivery (e.g. Meyers and Jones, 1993; Kember, 2001). Student-centred teaching emphasises the application of "active learning", in which students directly engage in their learning process through learning-by-doing and learning-by-learning. In-class participation is a component of the basic elements of active learning (talking and listening; the remaining are reading, writing and reflecting), which "involve cognitive activities that allow students to clarify, question, consolidate and appropriate new knowledge" (Meyers and Jones, 1993, p. 21). As a result, it contributes to students' development of independent learning skills, knowledge, and other deep learning attitudes that are beneficial to one's career.

\subsection{Teaching innovation}

A general definition of competency is the level of integration of knowledge, skills, and attitudes (Tigelaar et al., 2004). In the education literature, some of teachers' generic competencies is to build teachers' professional development (e.g. Koster et al., 2005; Runco, 2003). There are also many studies to focus on teachers' field competence, research competence, curriculum competence, lifelong learning competence, socialcultural competence, emotional competence, communication competence, information and communication technologies (ICT) competencies and environmental competencies as general teacher competencies (Hannon, 2008; Karwowski et al., 2007; Sahin and Thompson, 2006). However, there is a research gap which investigates the core competencies underlying teachers' innovative teaching. By reviewing related literature and integrating the main findings and results from the previous research, this current research postulates that three core competencies are considered important to underline teachers' innovative teaching: learning competency, educational competency, and social competency (Cairney, 2000; Chen, 2009; Ferrari et al., 2009; Lin, 2009; Pantic and Wubbels, 2010; Robison, 2001; Runco, 2007; Sternberg and Lubart, 1999). To us, this means that teaching and learning innovation practice focuses on the urgency of putting more emphasis on the first mentioned aspects.

\subsection{Teaching innovation and learning effectiveness}

When it comes to teaching innovation, according to Bruce (1989), "»learning« occurs in the interaction between the »learner« and the »learning environment«, when the appropriate strategies and methods were applied to use technology making it a favourable tool for teaching, then a better teaching effectiveness can be achieved". Teaching innovation means the teachers having creativity, being able to reflect on, to design and to apply new, diverse teaching methods or activities, understanding individual

\section{The Effect of Teaching Innovation on Learning Effectiveness among the Students of Taiwan and Universities} Mainland China 
IJSR 7

differences of students, stimulating students learning motivation and interest, enhancing the students learning effectiveness in the preparation before teaching, in the process of teaching and in student assessment (Chen, 2010). In short, teaching innovation is teachers having creativity and showing vivid and lively teaching strategies to make students interested in learning, thus enhancing the teaching effectiveness of teachers. In this article, it is suggested that a practice-theoretical approach provides a good basis for teaching and learning innovation in higher education and marketing courses. In this case study, it is explored how a practice-oriented model of teaching and learning has been injected into the education study curriculum of Taiwan and Mainland China higher education institutions.

\section{Methodology}

According to the criteria of Daniel's extraction for critical success factors, this study applies grey relational analysis (GRA) to analysing the differences of learning factors for Taiwanese and Mainland Chinese students, to exploring the feedback on learning marketing course. The result expects to improve teaching effect during this process. Furthermore, Chung Hsing University in Taiwan has obtained funding as part of the Ministry of Education's program - the Aim for the Top University Plan and Sun Yat-sen University in Mainland China is one of the universities sponsored by the key Project 985 which provided funding to the University. Both these institutions, were selected as the representative samples of both countries. Finally, marketing course was selected in this study, as both (China and Taiwan) are the same East Chinese societies, which can reduce the data differences caused by different teaching methods.

\subsection{Questionnaire design and recycle}

There are 26 factors in the questionnaire (see Table 1), divided into five dimensions in this study, including "Learning intention", "Practical skills", "Teamwork", "Professional knowledge" and "Creativity". This study uses the GRA of all the factors without subdividing them into each category as there were few factors in each category. Participants are required to choose the agreement level of each factors based on their own learning effect assessment, including the time point of the beginning and the end of the semester. This paper not only investigates the fact that students have some viewpoint changes about course learning after a semester, but also compares differences of self-learning outcomes between Taiwanese and Mainland Chinese students. The total repeated questionnaire of Taiwan and Mainland China are 24 and 49 at the beginning of the semester, and 28 and 46, respectively, at the end of the term as well.

\section{Results}

Daniel (1961) has mentioned that there are three to six "critical factors" for success. Also, critical factors cannot exceed half of the total number of factors; otherwise, they will lose their representative aspect. Such methods of analysing success factors can be applied in enterprises, questionnaires and so on. The GRA ranking at the beginning and end of Taiwan and Mainland China marketing course is showed in Table 1. 


\begin{tabular}{|c|c|c|c|c|c|}
\hline Code & Factors & $\begin{array}{c}\text { Taiwan } \\
\text { (beginning) }\end{array}$ & $\begin{array}{c}\text { Mainland } \\
\text { China } \\
\text { (end) }\end{array}$ & $\begin{array}{c}\text { Taiwan } \\
\text { (beginning) }\end{array}$ & $\begin{array}{l}\text { Mainland } \\
\text { China } \\
\text { (end) }\end{array}$ \\
\hline A1 & I am interested in this subject. & 0.652 & 0.594 & 0.654 & 0.540 \\
\hline A2 & $\begin{array}{l}\text { I will take the initiative to explore the relevant management } \\
\text { issues of business. }\end{array}$ & 0.534 & 0.465 & 0.600 & 0.505 \\
\hline A3 & I usually read books related to this subject. & 0.553 & $0.732^{*}$ & 0.556 & 0.447 \\
\hline A4 & I am confident in maintaining attendance at this course. & $0.826^{*}$ & $0.819^{*}$ & $0.815^{*}$ & $0.804^{*}$ \\
\hline A5 & $\begin{array}{l}\text { It usually raises my interest when something related to this } \\
\text { subject is being reported via media. }\end{array}$ & 0.569 & 0.542 & 0.595 & 0.533 \\
\hline A6 & $\begin{array}{l}\text { I can plan an appropriate process to solve the relevant } \\
\text { practical problems. }\end{array}$ & 0.555 & 0.574 & 0.600 & 0.590 \\
\hline A7 & $\begin{array}{l}\text { I can solve the relevant practical problems according to the } \\
\text { information analysis. }\end{array}$ & 0.581 & 0.582 & 0.615 & 0.574 \\
\hline A8 & $\begin{array}{l}\text { I can choose the appropriate method to solve the practical } \\
\text { problems of this subject. }\end{array}$ & 0.565 & 0.503 & 0.600 & 0.595 \\
\hline A9 & $\begin{array}{l}\text { I can plan an appropriate solution for the relevant practical } \\
\text { problems. }\end{array}$ & 0.512 & 0.554 & 0.586 & 0.597 \\
\hline A10 & $\begin{array}{l}\text { I can choose the appropriate application tools to solve the } \\
\text { practical problems of this subject. }\end{array}$ & 0.5 & 0.581 & 0.599 & 0.593 \\
\hline A11 & I can handle the conflicts of team members. & 0.625 & 0.700 & 0.535 & 0.640 \\
\hline $\mathrm{A} 12$ & I can accept different personal thoughts of team members. & $0.763^{*}$ & $0.803^{*}$ & $0.785^{*}$ & $0.702^{*}$ \\
\hline A13 & I can accept the opinion that is opposite to mine. & 0.736 & 0.646 & $0.721^{*}$ & 0.673 \\
\hline A14 & I can respect the opinion that is opposite to mine. & $0.781^{*}$ & $0.724^{*}$ & $0.770^{*}$ & $0.731^{*}$ \\
\hline A15 & I can completely express my thoughts. & 0.722 & 0.706 & 0.636 & 0.615 \\
\hline A16 & $\begin{array}{l}\text { I can always complete the task assigned by the team as } \\
\text { scheduled. }\end{array}$ & 0.673 & 0.710 & 0.678 & $0.748^{*}$ \\
\hline A17 & $\begin{array}{l}\text { I can work with my team members to finish the team work } \\
\text { successfully. }\end{array}$ & 0.694 & $0.795^{*}$ & $0.720^{*}$ & 0.670 \\
\hline A18 & $\begin{array}{l}\text { I am aware of the basic concepts relating to this subject at } \\
\text { present. }\end{array}$ & 0.534 & 0.601 & 0.517 & 0.539 \\
\hline A19 & I can reorganise the relevant knowledge of this subject. & 0.572 & 0.558 & 0.488 & 0.533 \\
\hline A20 & I can criticise the theory and practice of this subject. & $0.843^{*}$ & 0.552 & 0.434 & 0.560 \\
\hline A21 & $\begin{array}{l}\text { I am currently familiar with the basic knowledge of this } \\
\text { subject. }\end{array}$ & 0.506 & 0.540 & 0.535 & 0.583 \\
\hline A22 & $\begin{array}{l}\text { I can analyse the problems of enterprise using the theories of } \\
\text { this subject. }\end{array}$ & 0.527 & 0.561 & 0.464 & 0.492 \\
\hline A23 & I can create novel ideas to solve problems. & 0.454 & 0.520 & 0.529 & 0.583 \\
\hline A24 & $\begin{array}{l}\text { I can solve the relevant management issues in different } \\
\text { situations. }\end{array}$ & $0.871^{*}$ & 0.581 & 0.619 & 0.570 \\
\hline A25 & $\begin{array}{l}\text { I can consider solutions comprehensively while facing } \\
\text { complex relevant management issues. }\end{array}$ & 0.517 & 0.528 & 0.585 & 0.532 \\
\hline A26 & $\begin{array}{l}\text { I can always come up with creative ways to solve the } \\
\text { practical problems related to management. }\end{array}$ & 0.521 & 0.514 & 0.592 & 0.537 \\
\hline
\end{tabular}

The Effect of Teaching Innovation on Learning Effectiveness among the Students of Taiwan and Mainland China Universities

(na

Source: Authors' own study.

* critical factor

Table 1.

Factor code and value comparison 


\section{IJSR}

\section{7}

Figure 1.

The GRA result before marketing course in

Taiwan

\section{Figure 2.}

The GRA result before marketing course in Mainland China
Based on the GRA results, the rankings of factors before and after marketing course in Taiwan and Mainland China are shown in Figures 1-4. The study of Daniel (1961) is taken as the basis for selecting critical factors. For the above reasons and the reference of factor code provided in Table 1, each group of critical factors is shown as followed:

Five critical factors are selected at the beginning of Taiwan marketing course and they are: A24 (0.8716) as the top critical factor, followed by A20 (0.8439), A4 (0.8264), A14 (0.7817) and A12 (0.7639). Furthermore, five critical factors are selected at the end of Taiwan marketing course. These are the following: A4 (0.8150) in the first group, A12 (0.7857) and A14 (0.7701) in the second group, A13 (0.7211) and A17 (0.7202) in the third group.

On the contrary, five critical factors are selected at the beginning of Mainland China marketing course: A4 (0.8197), A12 (0.8033) and A17 (0.7959) in the first group, A3 (0.7324) and A14 (0.7245) in the second group. In addition, four critical factors are selected at the end of Mainland China marketing course and they are: A4 (0.8043) in the first group, A16 (0.7482), A14 (0.7319) in the second group and A12 (0.7029) in the third group.

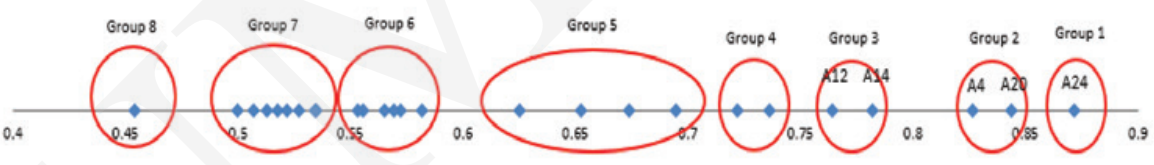

Source: Authors'own study.

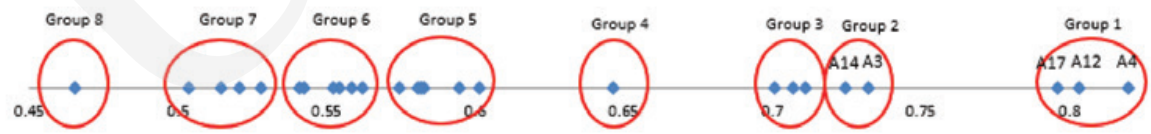

Source: Authors' own study.

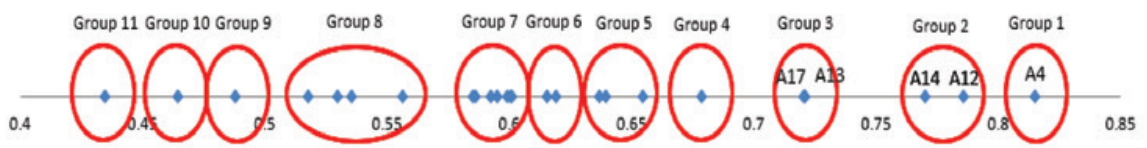

Source: Authors' own study.

Figure 4.

The GRA result after marketing course in Mainland China

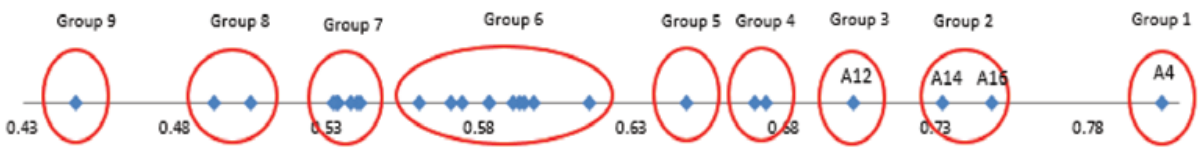

Source: Authors' own study. 


\subsection{Comparison of students' viewpoints on learning outcomes in both countries before and after the marketing course}

The purpose of this study is to explore how to modify the teaching methods in order to improve the learning effectiveness of students in both countries. In addition, in this section, the comparison of learning effectiveness and teaching innovation in both countries is examined. Table 2 shows the comparison of critical factors.

\begin{tabular}{|c|c|c|}
\hline & Taiwan & Mainland China \\
\hline \multirow{5}{*}{$\begin{array}{l}\text { Before the } \\
\text { course }\end{array}$} & $\begin{array}{l}\text { A24* I can solve the relevant management issues } \\
\text { in different situations. }\end{array}$ & $\begin{array}{l}\text { A4* I am confident in maintaining attendance at this } \\
\text { course. }\end{array}$ \\
\hline & $\begin{array}{l}\text { A } 20 * \text { I can criticize the theory and practice of this } \\
\text { subject. }\end{array}$ & $\begin{array}{l}\text { A12* I can accept different personal thoughts of team } \\
\text { members. }\end{array}$ \\
\hline & $\begin{array}{l}\text { A4* I am confident in maintaining attendance at } \\
\text { this course. }\end{array}$ & $\begin{array}{l}\text { A17* I can work with my team members to finish the } \\
\text { team work successfully. }\end{array}$ \\
\hline & $\begin{array}{l}A 14^{*} \text { I can respect the opinion that is opposite to } \\
\text { mine. }\end{array}$ & A3* I usually read books related to this subject. \\
\hline & $\begin{array}{l}\text { A12* I can accept different personal thoughts of } \\
\text { team members. }\end{array}$ & $\mathrm{A} 14^{*}$ I can respect the opinion that is opposite to mine. \\
\hline \multirow{5}{*}{$\begin{array}{l}\text { After the } \\
\text { course }\end{array}$} & $\begin{array}{l}\mathrm{A}^{*}{ }^{*} \text { I am confident in maintaining attendance at } \\
\text { this course. }\end{array}$ & $\begin{array}{l}\text { A4* I am confident in maintaining attendance at this } \\
\text { course. }\end{array}$ \\
\hline & $\begin{array}{l}\text { A12* I can accept different personal thoughts of } \\
\text { team members. }\end{array}$ & $\begin{array}{l}\text { A16* I can always complete the task assigned by the } \\
\text { team as scheduled. }\end{array}$ \\
\hline & $\begin{array}{l}\text { A14* I can respect the opinion that is opposite to } \\
\text { mine. }\end{array}$ & A14* I can respect the opinion that is opposite to mine. \\
\hline & $\begin{array}{l}\text { A13* I can accept the opinion that is opposite to } \\
\text { mine. }\end{array}$ & $\begin{array}{l}\text { A12* I can accept different personal thoughts of team } \\
\text { members. }\end{array}$ \\
\hline & $\begin{array}{l}\text { A17* I can work with my team members to finish } \\
\text { the team work successfully. }\end{array}$ & \\
\hline
\end{tabular}

Source: Authors' own study.

* critical factor

Therefore, this study has analysed the learning effectiveness of Taiwanese and Mainland Chinese students between the beginning and the end of learning marketing course, respectively, in order to compare the viewpoints and differences in terms of learning outcomes between these two groups. Moreover, this study has compared and examined the differences of both groups' learning effectiveness and teaching innovation, respectively.

\subsection{Critical factors of comparison between Taiwan and Mainland China before the course}

This section regards the comparison of two groups. Table 3 shows the comparison of top ten ranking of the GRA results between Taiwan and Mainland China before the course. In this study, there were found three key factors:
The Effect

of Teaching Innovation

on Learning Effectiveness among the Students of Taiwan and Mainland China Universities

Table 2.

Comparison of critical factors before and after the course 


\section{IJSR}

\section{7}

Table 3.

The GRA result at the beginning of marketing course between Taiwan and Mainland China
Table 4.

The GRA result at the end of marketing course between Taiwan and Mainland China
1) The most critical factors for the study were A4, A12, and A14 for Taiwanese or Mainland Chinese students. That is to say, students in both countries have confidence in attendance and teamwork at the beginning of the course.

2) The overall ranking of factors in the "teamwork" dimension is significantly higher than that of other categories for both groups of students at the beginning of the course.

3) The differences of both countries at the beginning of the course can be learned from Table 3. Taiwanese students demonstrate creativity and the ability to criticise practice, while Mainland students think they have the basic knowledge of this subject and the habit of reading the relevant books.

\begin{tabular}{ccccccccccc}
\hline \multicolumn{1}{c}{ Rank } & $\mathbf{1}$ & $\mathbf{2}$ & $\mathbf{3}$ & $\mathbf{4}$ & $\mathbf{5}$ & $\mathbf{6}$ & $\mathbf{7}$ & $\mathbf{8}$ & $\mathbf{9}$ & $\mathbf{1 0}$ \\
\hline Taiwan (beginning) & A24* & A20* & A4* & A14* & A12* & A13 & A15 & A17 & A16 & A1 \\
\hline Mainland China (beginning) & A4* & A12* & A17* & A3* & A14* & A16 & A15 & A11 & A13 & A18 \\
\hline \multirow{2}{*}{ Differences in rank } & $\mathrm{A} 24$ & $\mathrm{~A} 20$ & $\mathrm{~A} 4$ & $\mathrm{~A} 14$ & $\mathrm{~A} 12$ & $\mathrm{~A} 13$ & $\mathrm{~A} 15$ & $\mathrm{~A} 17$ & $\mathrm{~A} 16$ & $\mathrm{~A} 1$ \\
& $\downarrow 13$ & $\downarrow 18$ & $\uparrow 2$ & $\downarrow 1$ & $\uparrow 3$ & $\downarrow 3$ & constant & $\uparrow 5$ & $\uparrow 3$ & $\downarrow 1$ \\
\hline
\end{tabular}

Source: Authors' own study.

Note: The difference in rank is based on the factor code "Taiwan (beginning)", which is compared with the code in "Mainland China (beginning)".

* critical factor

\subsection{Critical factors of comparison between Taiwan and Mainland China after the course}

There are three critical factors (see Table 4) to illustrate the comparison of factors after the course between two groups as followed by:

1) A4, A12 and A14 are the same critical factors of learning effectiveness in Taiwan and Mainland China marketing course.

2) It can be found that at the end of the course, the first six categories of factors are the same for both groups of students. More specifically, only A4 is part of the "learning intention" dimension and other five factors are part of the "teamwork" dimension.

3) Taiwanese students demonstrate interest and ability to adapt in marketing after the course, whereas the students from Mainland China demonstrate improvement on practical skills.

\begin{tabular}{lcccccccccc}
\hline \multicolumn{1}{c}{ Rank } & $\mathbf{1}$ & $\mathbf{2}$ & $\mathbf{3}$ & $\mathbf{4}$ & $\mathbf{5}$ & $\mathbf{6}$ & $\mathbf{7}$ & $\mathbf{8}$ & $\mathbf{9}$ & $\mathbf{1 0}$ \\
\hline Taiwan (end) & $\mathbf{A 4}$ & $\mathbf{A 1 2}$ & $\mathbf{A 1 4}$ & $\mathbf{A 1 3}$ & $\mathbf{A 1 7}$ & $\mathrm{A} 16$ & $\mathrm{~A} 1$ & $\mathrm{~A} 11$ & $\mathrm{~A} 15$ & $\mathrm{~A} 24$ \\
\hline Mainland China (end) & $\mathbf{A 4}$ & $\mathbf{A 1 6 *}$ & $\mathbf{A 1 4}$ & $\mathbf{A 1 2 *}$ & $\mathrm{A} 13$ & $\mathrm{~A} 17$ & $\mathrm{~A} 11$ & $\mathrm{~A} 15$ & $\mathrm{~A} 9$ & $\mathrm{~A} 8$ \\
\hline \multirow{2}{*}{ Differences in rank } & $\mathrm{A} 4$ & $\mathrm{~A} 12$ & $\mathrm{~A} 14$ & $\mathrm{~A} 13$ & $\mathrm{~A} 17$ & $\mathrm{~A} 16$ & $\mathrm{~A} 1$ & $\mathrm{~A} 11$ & $\mathrm{~A} 15$ & $\mathrm{~A} 24$ \\
& constant & $\downarrow 2$ & constant & $\downarrow 1$ & $\downarrow 1$ & $\uparrow 4$ & $\downarrow 11$ & $\uparrow 1$ & $\uparrow 1$ & $\downarrow 6$ \\
\hline
\end{tabular}

Source: Authors' own study.

Note: The difference in rank is based on the factor code "Taiwan (end)", which is compared with the code in "Mainland China (end)".

* critical factor 


\subsection{Critical factors of comparison before and after the marketing course in Taiwan}

After understanding the comparison of the two country's students, this section shows Taiwanese students' learning results in terms of using teaching innovation. Table 5 illustrates the top ten ranking of the GRA results of the comparison before and after the marketing course in Taiwan. The results have shown that:

1) A4, A12 and A14 are all the critical factors at the beginning and the end of the course. It is clearly known that Taiwanese students have recognised the learning effectiveness with regard to teamwork of this course. The confidence in maintaining attendance (A4) has also shown the interest in this courses among Taiwanese students.

2) A20 and A24 are both the critical factors at the beginning of the course, while having a significant decrease of GRA ranking at the end of course. A20 and A24 have declined after the course as Taiwanese students do no thave the slightest idea about practice marketing in real world when compared to marketing knowledge in classes.

\begin{tabular}{ccccccccccc}
\hline \multicolumn{1}{c}{ Rank } & $\mathbf{1}$ & $\mathbf{2}$ & $\mathbf{3}$ & $\mathbf{4}$ & $\mathbf{5}$ & $\mathbf{6}$ & $\mathbf{7}$ & $\mathbf{8}$ & $\mathbf{9}$ & $\mathbf{1 0}$ \\
\hline Taiwan (beginning) & A24* & A20* & A4* & A14* & A12* & A13 & A15 & A17 & A16 & A1 \\
\hline Taiwan (end) & A4* & A12* & A14* & A13* & A17* & A16 & A1 & A11 & A15 & A24 \\
\hline \multirow{2}{*}{ Differences in rank } & $\mathrm{A} 24$ & $\mathrm{~A} 20$ & $\mathrm{~A} 4$ & $\mathrm{~A} 14$ & $\mathrm{~A} 12$ & $\mathrm{~A} 13$ & $\mathrm{~A} 15$ & $\mathrm{~A} 17$ & $\mathrm{~A} 16$ & $\mathrm{~A} 1$ \\
& $\downarrow 9$ & $\downarrow$ outside the rank & $\uparrow 2$ & $\uparrow 1$ & $\uparrow 3$ & $\uparrow 2$ & $\downarrow 2$ & $\uparrow 3$ & $\uparrow 3$ & $\uparrow 3$ \\
\hline
\end{tabular}

Source: Authors' own study.

* critical factor

\subsection{Critical factors of comparison before and after the marketing course in Mainland China}

This section explains the factors before and after the course in Mainland China:

1) A4, A12 and A14 are all critical factors regardless the beginning and the end of the course, which means that students from Mainland China are confident in maintaining attendance and teamwork of this course.

2) Students from Mainland China are more confident in "teamwork" at the beginning of the marketing course.

3) Compared with Table 1, it can be found that A8 and A9 have a significant increase in the ranking. It can be clearly shown that the Mainland students demonstrate increasing confidence in "practical skills" after a semester of this course.

4) It is worth noticing that the ranking of $A 3$ drops from the original 4 to the last. That is due to the fact that students are busy with studying in the semester.

\begin{tabular}{|c|c|c|c|c|c|c|c|c|c|c|}
\hline Rank & 1 & 2 & 3 & 4 & 5 & 6 & 7 & 8 & 9 & 10 \\
\hline Mainland China (beginning) & $\mathrm{A} 4 *$ & A12* & A17* & $\mathrm{A} 3 *$ & A14* & A16 & A15 & A11 & A13 & A18 \\
\hline Mainland China (end) & $\mathrm{A} 4^{*}$ & A16* & A14* & A12* & A13 & A17 & A11 & A15 & A9 & A8 \\
\hline Differences in rank & $\begin{array}{c}\text { A4 } \\
\text { constant }\end{array}$ & $\begin{array}{c}A 12 \\
\downarrow 2\end{array}$ & $\begin{array}{l}\text { A17 } \\
\downarrow 3\end{array}$ & $\begin{array}{c}\mathrm{A} 3 \\
\downarrow \text { to the last }\end{array}$ & $\begin{array}{c}\mathrm{A} 14 \\
\uparrow 2\end{array}$ & $\begin{array}{c}\mathrm{A} 16 \\
\uparrow 4\end{array}$ & $\begin{array}{l}A 15 \\
\downarrow 1\end{array}$ & $\begin{array}{l}\text { A11 } \\
\uparrow 1\end{array}$ & $\begin{array}{r}\mathrm{A} 13 \\
\uparrow 4\end{array}$ & $\begin{array}{c}\quad \text { A18 } \\
\downarrow \text { outside the rank }\end{array}$ \\
\hline
\end{tabular}

Source: Authors' own study.

* critical factor
The Effect

of Teaching Innovation

on Learning Effectiveness

among the

Students of

Taiwan and

Mainland China

Universities

\section{Table 5.}

The GRA result at the beginning and the end of marketing course in

Taiwan
Table 6.

The GRA result at the beginning and the end of marketing course in Mainland China 
IJSR 7

\section{Conclusions}

According to the results of this study, students in Taiwan and Mainland China have confidence in attendance and teamwork projects at the beginning of the marketing course. It is obvious that high attendance results from students' interest in this course and the fact that they expect to achieve knowledge about the subject at the beginning of the semester. Secondly, the "teamwork" dimension regards to the fact that students from both groups have tolerance for different opinions. Taiwanese students are confident about their own creativity and the ability of application at the beginning of the course and students from Mainland China have a regular habit of reading relevant marketing books. However, these critical factors at the beginning of the course are all replaced by the "teamwork" dimension at the end of the course. Compared with the ranking of other factors, it is found that Taiwanese students still have a certain degree of confidence about resilience, and "the interest in this course" has improved after the semester. On the other hand, students in Mainland China demonstrate improvement on their "practical skills" after this course. To sum up, Taiwanese students pay more attention to "creativity" and "the combination of interest and learning". In contrast, students in Mainland China are more concerned about "practical skills" and "accumulated learning effect step by step" (shown as A3) when compared to the Taiwanese students. Based on the above it can be concluded that educators should try to implement diversified teaching strategies and methods. Firstly, educators could arrange more group discussions during the course to stimulate students to expand their knowledge. Secondly, teachers could demonstrate a greater flexibility in arranging courses and give students the opportunity to use their creativity. Finally, educators could pay more attention to the combination of theory and practice, while arranging their curriculum, giving students more practical opportunities. When analysing and comparing these two cases, the authors of the article concentrated more on the learning process when teaching innovation is performed. Looking specifically at professions that share similar challenges in terms of teaching innovation implementation, enables us to see how other educators have responded to the challenges of preparing novices to create relationships with students that are crucial to the success of teaching practice. Therefore, further research should be focused on the specific learning processes, which occur in the classroom and concern students, teachers and other co-operators, during the implementation of innovation practice.

\section{References}

Biggs, J. (1987), Student Approaches to Learning and Studying, Australian Council for Educational Research, Hawthorn, Vic.

Bruce, R. (1989), "Creativity and instructional technology: Great potential, imperfectly studied", Contemporary Educational Psychology, vol. 14, no. 3, pp. 241-256.

Cairney, T. (2000), The Knowledge-Based Economy: Implications for Vocational Education and Training, Centre for Regional Research and Innovation, University of Western Sydney, Sydney.

Chen, S.C. (2009), A Study of the Relations Between Innovative Teaching Capacity and Teaching Effectiveness of Teachers in Elementary and Junior High Schools in Penghu County.

Chen, S.-M. (2010), "Empirical study of negative emotions of the reader services librarian at work. A case study of public libraries", Journal of Library and Information Science, vol. 8, no. 1 , pp. 3-12. 
Clift, R.T., and Brady, P. (2005), "Research on methods courses and field experiences", in: M. Cochran-Smith, K.M. Zeichner (eds.), Studying Teacher Education: The Report of the AERA Panel on Research and Teacher Education, Lawrence Erlbaum Associates, Mahwah, NJ, pp. 309-424.

Entwistle, N., and Ramsden, P. (1983), Understanding Student Learning, Croom Helm, London. Ferrari, A., Cachia, R., and Punie, Y. (2009), Literature Review on Innovation and Creativity in $E \& T$ in the EU Member States, Joint Research Centre, European Commission.

Hampden-Turner, Ch. (2009), Teaching Innovation and Entrepreneurship: Building on the Singapore Experiment, Cambridge University Press, New York.

Hannon, J. (2008), "Breaking down online teaching: Innovation and resistance", Proceedings ascilite 2008 Melbourne, pp. 389-399.

Jones, B.L. (1996), Self-efficacy and personal goals in classroom performance: The effect of task experience. A dissertation submitted to the Kent State University Graduate School of Management in partial fulfilment of the requirements for the degree of Doctor of Philosophy.

Karwowski, M., Gralewski, J., Lebuda, I., and Wiśniewska, E. (2007), "Creative teaching of creativity teachers: Polish perspective", Thinking Skills and Creativity, vol. 2, pp. 57-61.

Kember, D. (2001), "Beliefs about knowledge and the process of teaching and learning as a factor in adjusting to study in higher education", Studies in Higher Education, vol. 26, no. 2, pp. 205-221.

Koster, B., Brekelmans, M., Korthagen, F., and Wubbels, T. (2005), "Quality requirements for teacher educators", Teaching and Teacher Education, vol. 21, pp. 157-176.

Lin, C.D. (2009), Researches into Creative Talents and Creative Education, Economic Science Press, Beijing.

Loo, R. (1999), "Confirmatory factor analyses of Kolb's Learning Style Inventory (LSI-1985)", British Journal of Educational Psychology, vol. 69, pp. 213-219.

Marton, F., Dall'Alba, G. and Beaty, E. (1993), "Conceptions of learning", International Journal of Educational Research, vol. 19, pp. 277-300.

Meyers, C., and Jones, T.B. (1993), Promoting Active Learning: Strategies for College Classrooms, Jossey-Bass Publishers, San Francisco.

Pantic, N., and Wubbels, T. (2010), "Teacher competencies as a basis for teacher education-views of Serbian teachers and teacher educators", Teaching, vol. 26, no. 3, pp. 694-703.

Robinson, K. (2001), Out of Our Minds: Learning to Be Creative, Capstone, Oxford.

Runco, M.A. (2003), "Education for creative potential", Scandinavian Journal of Educational Research, vol. 47, no. 3, pp. 317-324.

Runco, M.A. (2007), Creativity: Theories and Themes: Research, Development, and Practice, Elsevier Academic Press, London.

Sahin, I., and Thompson, A. (2006), "Using Rogers' theory to interpret instructional computer use by COE faculty", Journal of Research on Technology in Education, vol. 39, no. 1, pp. 81-104.

Saljo, R. (1979), Learning in the learner's perspective. I. Some common sense conceptions. Reports from the Institute of Education, University of Gothenburg, no. 77.

Sternberg, R.J., and Lubart, T.I. (1999), “The concept of creativity: Prospects and paradigms”, in: R.J. Sternberg (ed.), Handbook of Creativity, Cambridge University Press, Cambridge, pp. 3-15.

Tigelaar, D.E.H., Dolmans, D.H.J.M., Wolfhagen, I.H.A.P., and van der Vleuten, C.P.M. (2004), "The development and validation of a framework for teaching competencies in higher education", Higher Education, vol. 48, no. 2, pp. 253-268.

\section{The Effect of Teaching Innovation on Learning Effectiveness among the Students of Taiwan and Universities} Mainland China 